\title{
Numerical Modeling on Fuel Cell Cooling using Water Based Aluminum Nitride Nanofluid
}

\author{
N. K. Kund
}

\begin{abstract}
In the trendy research, CFD codes got developed and run with water-AIN nanofluid to predict the thermal concerns of fuel cell. The convective governing equalities of mass, force and drive are computed for predicting the thermal issues of fuel cell. The time step selected throughout the intact computation is 0.0001 s. The soundings affect CFD forecasts of temperature field, temperature contour plus fluid-solid boundary temperature of fuel cell. The fluid-solid boundary temperature of fuel cell is noticed as $320 \mathrm{~K}$. This stands far less than the hazardous limit of $356 \mathrm{~K}$ temperature desired for the objective of beating thermal cataclysm of fuel cell. The temperature of water-AIN nanofluid stands peak contiguous to the fuel cell vicinity. Additionally, the temperature of water-AIN nanofluid gently drops with improvement in remoteness from fuel cell. Subsequently, this becomes surrounding temperature in the distant field zone. The corresponding tinted temperature contour stands accessible. In addition, the congruent plot of temperature against distance from fuel cell stays revealed. The development of CFD revelations stand together with the credentials of undertakings.
\end{abstract}

Index Terms: Fuel Cell, Cooling, CFD Codes, Water-AIN Nanofluid.

\section{INTRODUCTION}

A signal of thermal dissipations in fuel cell stays established in figure 1. Fuel cell heat dissipation caught numerous routines for illustration.The standard heat dissipation arrayed heretofore for instance, atmospheric convection is inappropriate for extreme thermal flux treatments. Still, in the preceding years the strange way of heat dissipation has compelled the researchers' ubiquitously within the sphere for the humdrum of nanofluid heat control.

Furthermore, the nanofluid thermal dissipation is unequivocally spirited as ambient heat dissipation is poor to deliver the drive. Numerical and experimental reviews on heat spreading over rectangular domain are existent in texts [1-7]. Computational and experimental work with solidification also stand presented [8-20].

Nevertheless of the realities that the nanofluid cooling equivocates the issues about the extreme heat battle as to ambient heat dissipation and hence, the treatment of nanofluid remains the significant drive of the extant exploration. Here,

Manuscript published on 30 September 2019

* Correspondence Author

N. K. Kund, Department of Production Engineering, Veer Surendra Sai University of Technology, Burla (Sambalpur), Odisha, India.

(C) The Authors. Published by Blue Eyes Intelligence Engineering and Sciences Publication (BEIESP). This is an open access article under the CC-BY-NC-ND license http://creativecommons.org/licenses/by-nc-nd/4.0/ the heat dissipations of fuel cell through water-AlN nanofluid stay explored numerically.

\section{DEMONSTRATION OF PHYSICAL PROBLEM}

Figure 2 divulges the physical theme course problem covering a heat generation from fuel cell indicating the top and bottom edges. Rest two edges are signposted through ambient situations. Here, the thermal dissipations from fuel cell is completed over water-AlN nanofluid.

Further, the thermophysical plus model data of AlN nanoparticles are reflected in the existent analysis plus the ambient situation involved in the current course computations, stand agglomerated exceptionally in Table 1.

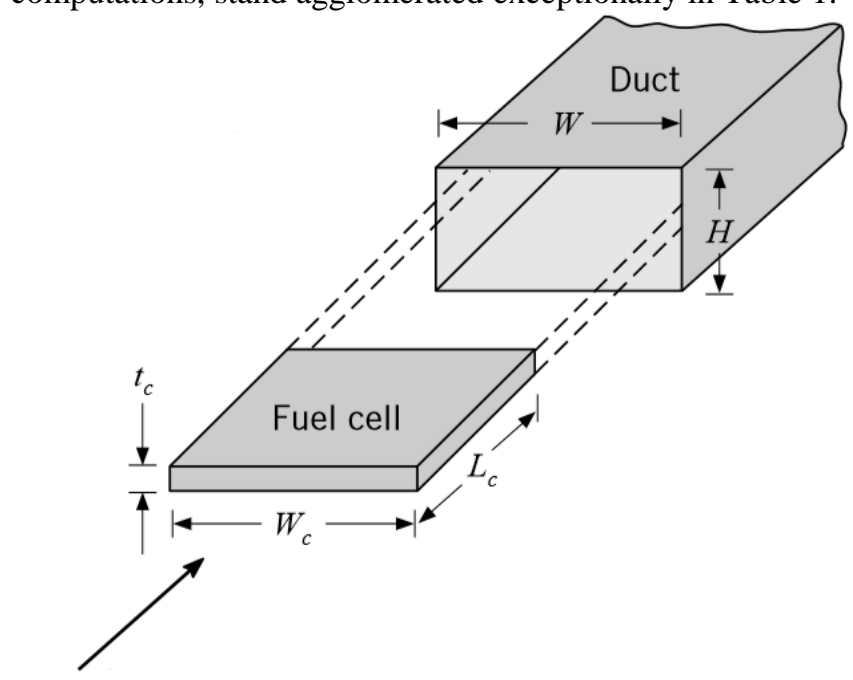

Coolant $\left(T_{c}, V_{c}\right)$

Figure 1. Fuel cell besides enclosure

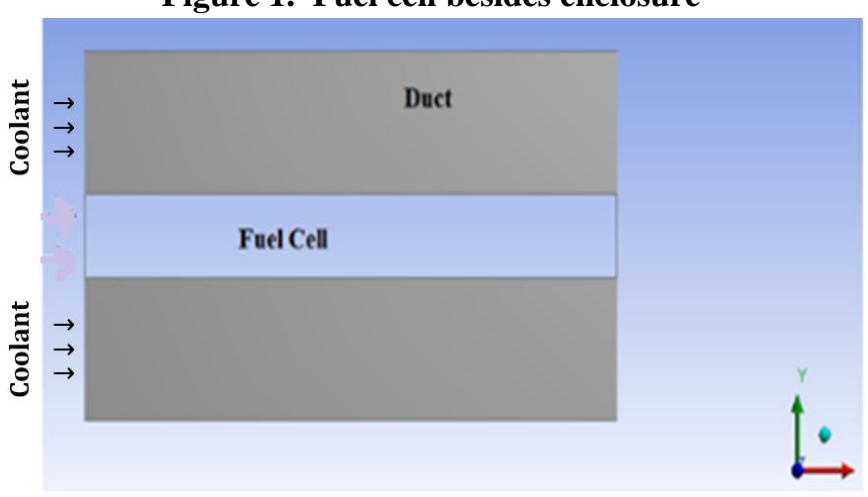

Figure 2. Computational domain

\section{NUMERICAL PROCEDURES}

As declared overhead, the figure 2 reveals the CFD worktable aimed at computing the physical topic course. 


\section{Numerical Modeling on Fuel Cell Cooling using Water Based Aluminum Nitride Nanofluid}

To facilitate the CFD forecasts the binding stages such as constructing geometry and purview, meshing and initialization are followed to run the simulation.

Here, the prevailing equalities (as termed below through equalities 1-4) of mass, force and drive beside the edge states are chosen. Linearized equalities are computed through the CFD codes. After the development of computations, CFD codes form the shapes and curls through that numerous graphs stand strained to amalgam the CFD forecasts through the prognoses. With the later dispensation the forecasts are scrupulously explored aimed at receiving profuse insights.

Continuity:

$$
\frac{\partial u}{\partial x}+\frac{\partial v}{\partial y}=0
$$

X-momentum:

$$
\rho\left(\frac{\partial u}{\partial t}+u \frac{\partial u}{\partial x}+v \frac{\partial v}{\partial y}\right)=-\frac{\partial p}{\partial x}+\mu\left(\frac{\partial^{2} u}{\partial x^{2}}+\frac{\partial^{2} u}{\partial y^{2}}\right)
$$

Y-momentum:

$$
\rho\left(\frac{\partial v}{\partial t}+u \frac{\partial v}{\partial x}+v \frac{\partial v}{\partial y}\right)=-\frac{\partial p}{\partial y}+\mu\left(\frac{\partial^{2} v}{\partial x^{2}}+\frac{\partial^{2} v}{\partial y^{2}}\right)+\rho g
$$

Energy:

$$
\left(\frac{\partial T}{\partial t}+u \frac{\partial T}{\partial x}+v \frac{\partial T}{\partial y}\right)=\alpha\left(\frac{\partial^{2} T}{\partial x^{2}}+\frac{\partial^{2} T}{\partial y^{2}}\right)
$$

Table 1. Thermophysical properties and model data.

\begin{tabular}{|l|l|}
\hline Nanoparticle Properties & AIN \\
\hline Density, $\rho\left(\mathrm{Kg} / \mathrm{m}^{3}\right)$ & 3261 \\
\hline Specific heat, $C_{P}\left(\mathrm{~J} \mathrm{Kg}^{-1} \cdot \mathrm{K}^{-1}\right)$ & 741 \\
\hline Thermal conductivity, $k(\mathrm{~W} / \mathrm{m}-\mathrm{K})$ & 286 \\
\hline Model Data & Values \\
\hline Enclosure height $(\mathrm{H})$ & $25 \mathrm{~mm}$ \\
\hline Fuel cell length $\left(\mathrm{L}_{\mathrm{c}}\right)$ & $51 \mathrm{~mm}$ \\
\hline Thickness of fuel cell $\left(\mathrm{t}_{\mathrm{c}}\right)$ & $5 \mathrm{~mm}$ \\
\hline Fuel cell width $\left(\mathrm{W}_{\mathrm{c}}\right)$ & $51 \mathrm{~mm}$ \\
\hline Enclosure width $(\mathrm{W})$ & $51 \mathrm{~mm}$ \\
\hline Atmospheric temperature & $300 \mathrm{~K}$ \\
\hline Fuel cell heat flux & $10 \mathrm{~W} / \mathrm{cm}^{2}$ \\
\hline Coolant velocity & $8 \mathrm{~m} / \mathrm{s}$ \\
\hline
\end{tabular}

In the enduring examination, CFD codes are established and executed with water-AIN nanofluid to visualize the thermal concerns of fuel cell. The convective governing equalities of mass, force and drive are computed for envisaging the thermal issues of fuel cell. The time step selected in the integral iteration is $0.0001 \mathrm{~s}$.

\section{RESULTS AND DISCUSSIONS}

CFD codes stand established and executed with water-AlN nanofluid. It envisages the impacts on heat dissipation of fuel cell. The soundings affect CFD forecasts of temperature field, temperature contour plus fluid-solid boundary temperature of fuel cell.

\section{Effect of Water-AIN Nanofluid on Fuel Cell Cooling}

To expedite the scouting for the stimulus of water-AlN nanofluid on fuel cell cooling, the contemporaneous corporeal archetype stands computed numerically bearing in mind both thermophysical and model data regarding the standing positions.

Figure 3 discloses the CFD prognosis of temperature field besides the tinted measuring scale screening the temperature values over $\mathrm{K}$. It stands viewed at the documented archetype statuses bearing in mind the water-AlN nanofluid for fuel cell heat dissipation. The fluid-solid boundary temperature of fuel cell is viewed as $320 \mathrm{~K}$. This stands far less than the chancy limit of $356 \mathrm{~K}$ temperature wished for the objective of outwitting thermal cataclysm of fuel cell. Tritely, the temperature of water-AIN nanofluid stands peak contiguous to the fuel cell locality. Further, the temperature of water-AlN nanofluid gently drops with improvement in aloofness from fuel cell. Afterwards, this becomes surrounding temperature in the aloof arena precinct.

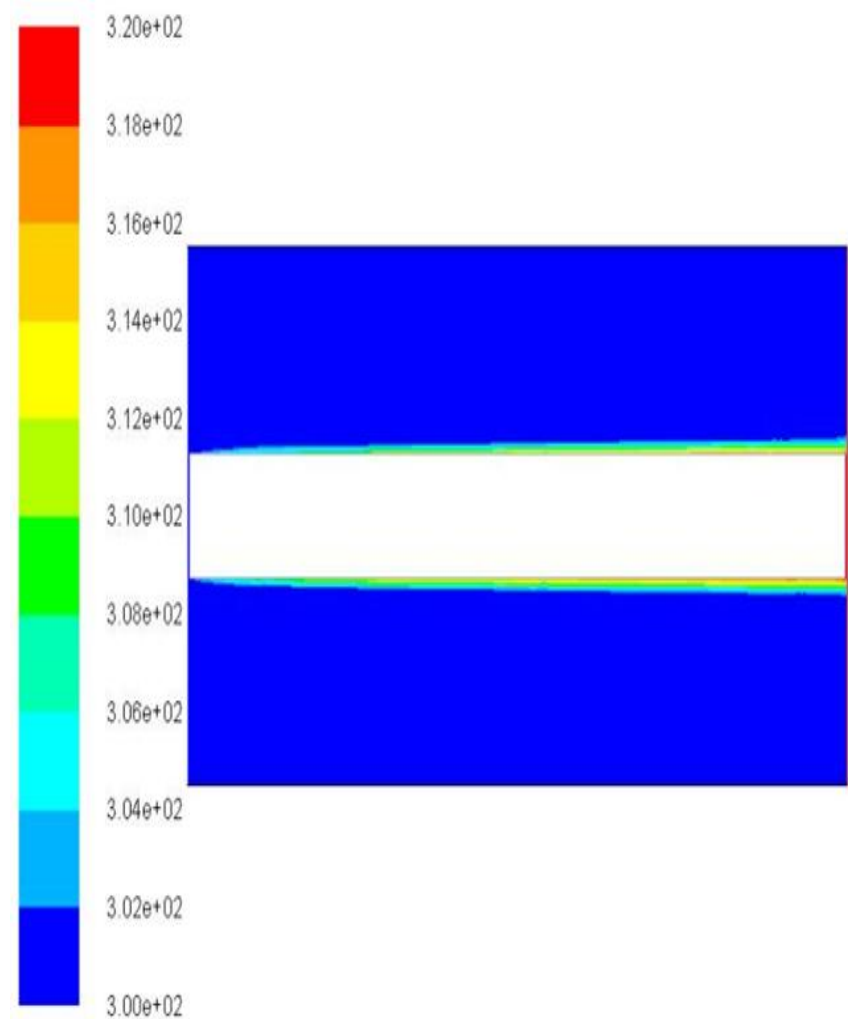

Figure 3. Temperature field with water-AIN nanofluid The equivalent tinted temperature contour stands accessible in figure 4 onwards. Besides, the harmonizing graph of temperature against distance from fuel cell stands revealed in figure 5. Tritely, the development of CFD elucidations stand along the structures of prospects. 


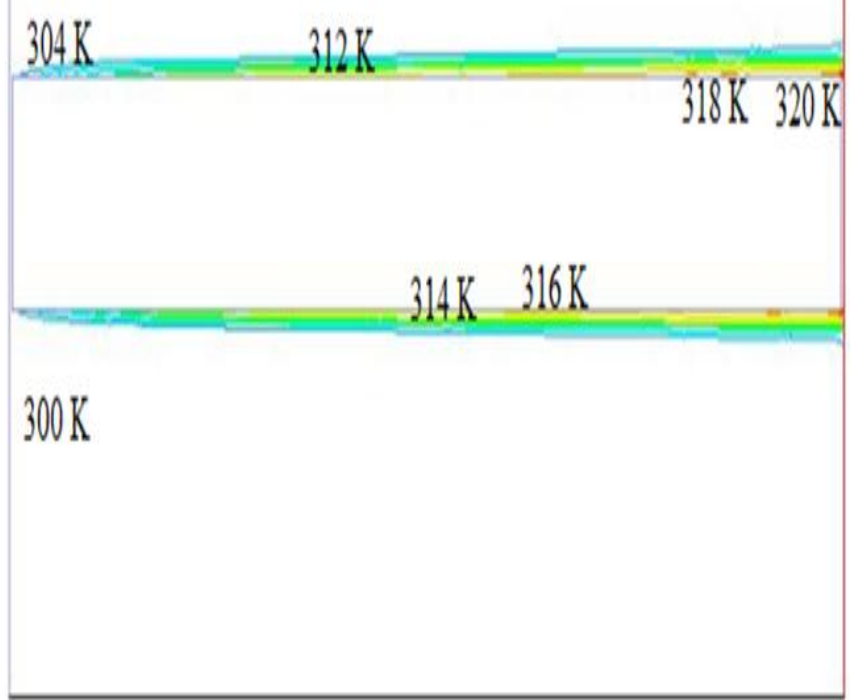

Figure 4. Temperature contour with water-AIN nanofluid

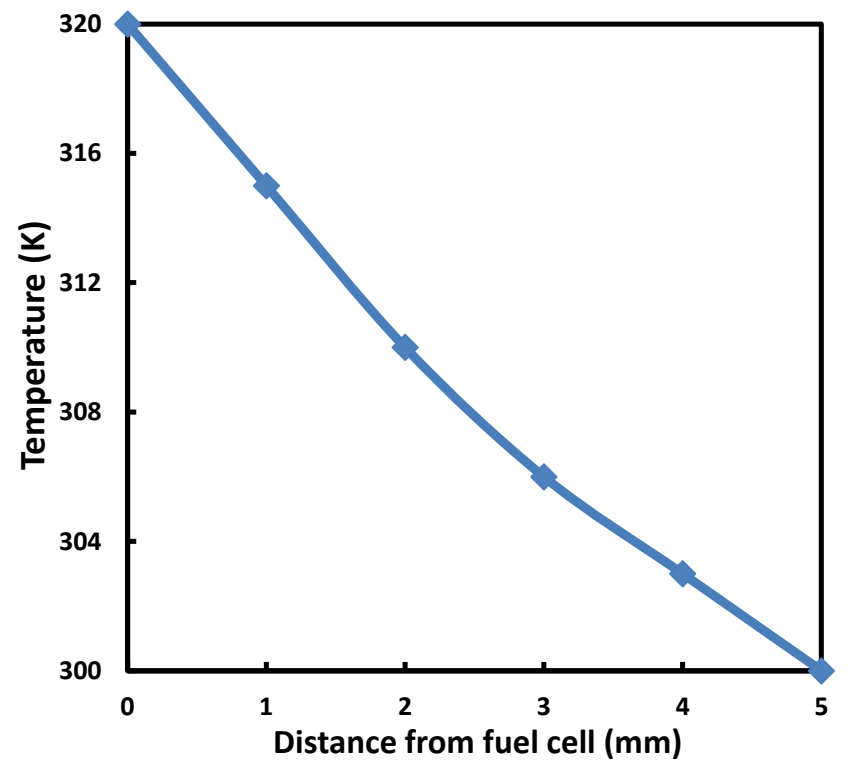

Figure 5. Temperature vs. distance from fuel cell

\section{CONCLUSION}

In the fashionable investigation, CFD programmes got developed and executed with water-AIN nanofluid to envision the thermal concerns of fuel cell. The convective governing equalities of mass, force and drive are computed for predicting the thermal issues of fuel cell. The time step selected throughout the intact computation is $0.0001 \mathrm{~s}$. The soundings affect CFD forecasts of temperature field, temperature contour plus fluid-solid boundary temperature of fuel cell. The fluid-solid boundary temperature of fuel cell is noticed as $320 \mathrm{~K}$. This stands far less than the hazardous limit of $356 \mathrm{~K}$ temperature desired for the objective of beating thermal cataclysm of fuel cell. The temperature of water-AlN nanofluid stands peak contiguous to the fuel cell vicinity. Additionally, the temperature of water-AIN nanofluid gently drops with improvement in remoteness from fuel cell. Subsequently, this becomes surrounding temperature in the distant field zone. The corresponding tinted temperature contour stands accessible. In addition, the congruent plot of temperature against distance from fuel cell stands publicized. The establishment of CFD revelations stay alongside the backgrounds of promises.

\section{ACKNOWLEDGMENT}

Necessary support from VSSUT Burla, for completing this document is greatly acknowledged. Truthfully, the author is thankful to the reviewers and journal editorial panel for their careful as well as innate reviews to this article.

\section{REFERENCES}

1. N. K. Kund, P. Dutta, 2010, Numerical simulation of solidification of liquid aluminium alloy flowing on cooling slope, Trans. Nonferrous Met. Soc. China, Vol. 20, pp. s898-s905.

2. N. K. Kund, P. Dutta, 2012, Scaling analysis of solidification of liquid aluminium alloy flowing on cooling slope, Trans. Indian Institute of Metals, Vol. 65, pp. 587-594.

3. N. K. Kund, 2014, Influence of melt pouring temperature and plate inclination on solidification and microstructure of A356 aluminum alloy produced using oblique plate, Trans. Nonferrous Met. Soc. China, Vol. 24, pp. 3465-3476.

4. N. K. Kund, 2015, Influence of plate length and plate cooling rate on solidification and microstructure of A356 alloy produced by oblique plate, Trans. Nonferrous Met. Soc. China, Vol. 25, pp. 61-71.

5. N. K. Kund, P. Dutta, 2015. Numerical study of solidification of A356 aluminum alloy flowing on an oblique plate with experimental validation, J Taiwan Inst. Chem. Ers., Vol. 51, pp. 159-170.

6. N. K. Kund, P. Dutta, 2016, Numerical study of influence of oblique plate length and cooling rate on solidification and macrosegregation of A356 aluminum alloy melt with experimental comparison, J. Alloys Compd., Vol. 678, pp. 343-354.

7. N. K. Kund, 2018, Effect of tilted plate vibration on solidification and microstructural and mechanical properties of semisolid cast and heat-treated A356 Al alloy, Int. J. Adv. Manufacturing Technol., Vol. 97, pp. 1617-1626.

8. N. K. Kund, 2019, EMS route designed for SSM processing, International Journal of Engineering and Advanced Technology, Vol. 8 , pp. $382-384$.

9. N. K. Kund, 2019, Cooling slope practice for SSF technology, International Journal of Engineering and Advanced Technology, Vol. 8 pp. 410-413.

10. N. K. Kund, 2019, Comparative ways and means for production of nondendritic microstructures, International Journal of Innovative Technology and Exploring Engineering, Vol. 8, pp. 534-537.

11. N. K. Kund, 2019, Simulation of electronics cooling deploying water-zinc oxide nanofluid, International Journal of Recent Technology and Engineering, Vol. 7, pp. 1076-1078.

12. N. K. Kund, 2019, Numerical studies on fuel cell cooling introducing water-copper nanofluid, International Journal of Recent Technology and Engineering, Vol. 7, pp. 1079-1081.

13. N. K. Kund, 2019, Computational modeling of fuel cell expending water-zinc oxide nanofluid, International Journal of Innovative Technology and Exploring Engineering, Vol. 8, pp. 424-426.

14. N. K. Kund, 2019, Investigations on modeling and simulation of electronics cooling exhausting water-aluminum nanofluid, International Journal of Innovative Technology and Exploring Engineering, Vol. 8, pp. 660-663.

15. N. K. Kund, 2019, Numerical study on effect of nozzle size for jet impingement cooling with water- $\mathrm{Al}_{2} \mathrm{O}_{3}$ nanofluid, International Journal of Engineering and Advanced Technology, Vol. 8, pp. 736-739.

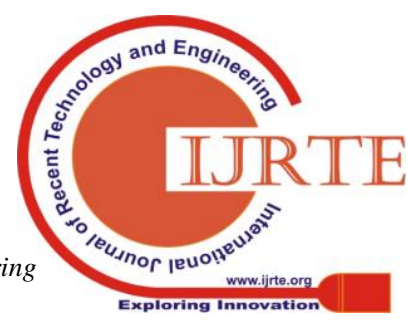




\section{Numerical Modeling on Fuel Cell Cooling using Water Based Aluminum Nitride Nanofluid}

16. N. K. Kund, 2019, Experimental investigations on impacts of nozzle diameter on heat transfer behaviors with water jet impingement, International Journal of Engineering and Advanced Technology, Vol. 8, pp. $745-748$.

17. N. K. Kund, 2019, Comparative CFD studies on jet impingement cooling using water and water- $\mathrm{Al}_{2} \mathrm{O}_{3}$ nanofluid as coolants, International Journal of Innovative Technology and Exploring Engineering, Vol. 8, pp. 545-548.

18. N. K. Kund, 2019, Experimental studies on effects of jet Reynolds number on thermal performances with striking water jets, International Journal of Innovative Technology and Exploring Engineering, Vol. 8, pp. 2195-2198.

19. N. K. Kund, D. Singh, 2019, CFD studies on heat transfer and solidification progress of A356 al alloy matrix and $\mathrm{Al} 2 \mathrm{O} 3$ nanoparticles melt for engineering usages, International Journal of Innovative Technology and Exploring Engineering, Vol. 8, pp. 2043-2046.

20. N. K. Kund, S. Patra, 2019, Simulation of thermal and solidification evolution of molten aluminum alloy and $\mathrm{SiC}$ nanoparticles for engineering practices, International Journal of Innovative Technology and Exploring Engineering, Vol. 8, pp. 2047-2050.

\section{AUTHORS PROFILE}

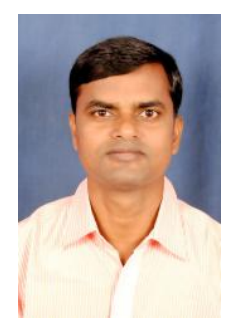

Dr. N. K. Kund has obtained both M.Tech. \& Ph.D. in Mechanical Engineering from Indian Institute of Science Bangalore. He has also obtained B.Tech.(Hons) in Mechanical Engineering from IGIT Sarang, Utkal University Bhubaneswar. He has published several research papers in international journals and also guided many research scholars, besides, wide teaching and research experience. He is presently working as Associate Professor in the Department of Production Engineering, VSSUT Burla (A

Government Technical University). 